\title{
UNDERSTANDING AND OVERCOMING CHALLENGES IN ACCESSING THE AFRICAN COURT ON HUMAN AND PEOPLES' RIGHTS
}

\author{
FRANS VILJOEN*
}

\begin{abstract}
This contribution examines access to the African Court on Human and Peoples' Rights in the first decade of its operation. Compared with other regional human rights Courts the African Court has decided more contentious cases. Direct access accounts for this difference. Acceptance by States of optional direct access is a necessary but insufficient condition for actual access. The reasons for the Commission's reluctance to refer cases, which hampered indirect access to the Court, are investigated. Although the Court's advisory jurisdiction has found limited application, it has welcomed amici curiae and showed some acceptance of the role of original complainants before the Court.
\end{abstract}

Keywords: access, advisory jurisdiction, African Commission on Human and Peoples' Rights, African Court of Human and Peoples' Rights, amicus curiae, Article 34(6) of the African Court Protocol, direct access, jurisdiction, standing of original complainant.

\section{INTRODUCTION}

In 2006, the African Union (AU) celebrated not only 30 years since the entry into force of the African Charter on Human and Peoples' Rights (African Charter), ${ }^{1}$ marking the birth of the regional human rights system established under the auspices of its predecessor, the Organisation of African Unity (OAU), but also ten years since the African Court on Human and Peoples' Rights (African Court) started functioning. ${ }^{2}$ The African Court was brought

\footnotetext{
* Professor, Faculty of Law Centre for Human Rights, University of Pretoria. frans.viljoen@, up.ac.za

1 The African Charter was adopted on 27 June 1981, in Nairobi, Kenya; and entered into force on 21 October 1986, after a simple majority of OAU member States had ratified or acceded to it.

2 The African Court was established by the Protocol to the African Charter on the Establishment of an African Court on Human and Peoples' Rights, which was adopted on 10 June 1998, in Ouagadougou, Burkina Faso, and entered into force on 25 January 2004 when the requisite 15 States had ratified the Protocol. The period between 2004 and 2006 was one of inactivity. Judges were only elected in January 2006 (Assembly/AU/Dec.100 (VI)), after the process was delayed due to the AU Assembly's decision in July 2004 that the African Court and the AU Court of Justice should be integrated into one Court (Assembly/AU/Dec.45 (III)). Only in July 2005 did the Assembly decide (Assembly/AU/Dec.83(V)) that the election of the Judges should take place, pending the merger of the two Courts. The first 11 elected Judges were
} 
into being to complement the protective mandate of the African Commission on Human and Peoples' Rights (African Commission). ${ }^{3}$ By providing for the possibility of judicial (and thus unequivocally binding) decisions, the Court adds an important dimension to the quasi-judicial mandate of the African Commission. As an important element of its rationale, the African Court's accessibility provides a fitting prism through which to view the progress of the Court over the first decade of its operation.

This article therefore aims to analyse access to the African Court between 2006 and $2016 .{ }^{4}$ For the purpose of this article, the concept of 'access' is understood as the competence to approach a human rights system in order to (a) obtain a remedy (in a contentious case); (b) be represented as victim (personally or through a legal representative) before the Court (in contentious proceedings); (c) solicit an advisory opinion, and (d) contribute to Court proceedings as amicus curiae. Although other aspects are also undeniably relevant to access, such as the access of third party States, ${ }^{5}$ access resulting in amicable settlement, ${ }^{6}$ and in provisional measures, ${ }^{7}$ the four selected facets best capture the Court's trajectory over its first decade. This article has four substantive parts. The first relates to contentious proceedings, either by way of direct or indirect access to the Court. The second discusses the legal position and emerging Court practice related to victims or their representatives being represented before the Court when the African Commission has referred a case to the Court. The third part looks at access to the Court's advisory competence. In the fourth part, the extent to which amici curiae may potentially and have in fact gained access to the Court is discussed. Each of these parts deals with the potential for, the actual extent of, and the obstacles to access. The last part of the article draws the findings together and recommends some measures to improve access to the Court.

inaugurated on 2 July 2006; and the Court had its first session from 2 to 5 July 2006, in Banjul, The Gambia.

3 Court Protocol, art 2; see also F Viljoen, International Human Rights Law (Oxford University Press 2012) 414-20.

4 By analysing actual practice, this article differs from a more speculative contribution on access to the African Court, published in 2007 (D Juma, 'Access to the African Court on Human and Peoples' Rights: A Case of the Poacher turned Gamekeeper' (2007) 4 Essex Human Rights Review 1 .

5 In terms of art 5(2) of the Court Protocol, as a State party that 'has an interest' in the case: in Guehi v Tanzania, App 1/2015, Côte d'Ivoire intervened on this basis, as its national was bringing an application, and the Court considered the issuance of a provisional order.

6 Amicable settlement, which may also be viewed as a form of remedy, has so far not been reached under the Court's auspices, and is not discussed here.

7 The Court delivered 13 orders for provisional measures: African Commission v Lybia ((Bengazi), App 4/2011, Order for Provisional Measures (25 March 2011); African Commission v Lybia ((Saif Al-Islam Kadhafi), App 2/2013, Order for Provisional Measures (15 March 2013); African Commission v Kenya (Ogiek). App 6/2012, Order for Provisional Measures (15 March 2013); Konate v Burkina Faso, App 4/2013, Order for Provisional Measures (4 October 2013); and a further nine Orders for Provisional Measures cited in note 47 below. Even if they are only interim in nature, provisional orders are also remedial. However, given the different issues involved, and the number of orders, these orders are not included in the scope of this article. 
II. CONTENTIOUS PROCEEDINGS

There are two ways in which contentious proceedings related to the merits of a case may become a matter for the Court's decision: direct access to the Court, or indirect access (via the African Commission). The (as yet unrealized) possibility of indirect access via the African Committee of Experts on the Rights and Welfare of the Child (African Children's Rights Committee) must also be considered.

\section{A. Direct Access}

In the first decade of the Court's existence, most cases reached the Court by way of individuals or NGOs directly accessing the Court after having exhausted domestic remedies.

Direct access is dependent on a State having fulfilled three cumulative conditions. First, it must be a State party to the African Charter. In 2016, all 54 African Union (AU) member States were parties to the Charter. ${ }^{8}$ Second, the State must have ratified the Protocol to the African Charter on the Establishment of the African Court on Human and Peoples' Rights (African

Q3 Court Protocol). By the end of 2016, 30 States have done so. ${ }^{9}$ Third, it must have made a declaration under Article 34(6) of the Court Protocol, accepting the competence of individuals and non-governmental organizations (NGOs) (enjoying observer status with the African Commission) to directly access the Court. Eight States have by 31 December 2016 made this declaration. In chronological order of depositing their declarations, they are: Burkina Faso (1998), Malawi (2008), Mali (2010), Tanzania (2010), Ghana (2011), Côte d'Ivoire (2013), Rwanda (2013) and Benin (2016). It is encouraging that seven of these declarations have been made since the Court started its operations (in 2006) and after the first case had been submitted to it (in 2008). ${ }^{10}$ It remains to be seen, though, if this trend would continue as the Court's substantive judgments and provisional orders start enjoying greater exposure and prominence, and more cases are submitted against those States that have already made Article 34(6) declarations.

Regrettably, on 1 March 2016, Rwanda withdrew its declaration. In a subsequent decision, ${ }^{11}$ the Court held that this withdrawal is valid. The Court reasoned that, because making the declaration is optional, the possibility of withdrawing it should also be open to the State. ${ }^{12}$ However, the Court further

\footnotetext{
${ }^{8}$ The number of AU member States has, with the readmission of Morocco in January 2017,

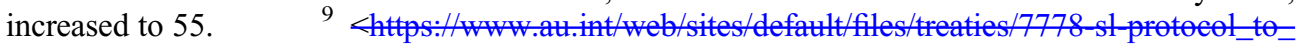
the_african_charter_on_human_and_peoplesrights_on_the_establishment_of_an_african_court_on_ hmman_and_peoples_rights_17.pdf>.

10 Yogogombaye v Senegal, App 1/2008, Judgment (15 December 2009).

11 Inbabire Victoire Umuhoza v Rwanda, App 3/2014, Ruling on Jurisdiction (3 June 2016) (Indrawal).

${ }_{12}$ 'As far as unilateral acts are concerned, state sovereignty commands that state are free to commit themselves and that they retain discretion to withdraw their commitments'.
} 
held that, although a State may unilaterally withdraw, its discretion to do so only becomes effective a year after the declaration has been deposited. The Rwandan declaration therefore only took effect on 1 March 2017. Going by the general principle of non-retroactivity of treaties, ${ }^{13}$ this withdrawal does not affect cases already pending before the Court; and also did not prevent the submission of new cases against Rwanda until 1 March 2017. ${ }^{14}$ The government cited as the main reason for its withdrawal that it 'never envisaged' that fugitives from justice would by virtue of the declaration have 'secured the right to be heard' by the Court. ${ }^{15}$ Rwanda's concern related in particular to Kayumba Nyamwasa, convicted for crimes pertaining to State security and sectarianism, and Safari Stanley, convicted of genocide. They have both fled Rwanda and while exiled in South Africa, submitted a case contending that the amendment of Article 101 of the Constitution of Rwanda, which would extend the presidential term beyond its current limit, violates the African Charter. ${ }^{16}$ However, the government's reasoning is disingenuous, As Article 34(6) does not qualify the kinds of NGOs or individuals entitled to submit cases alleging violations of the relevant human rights treaties. Also, indirect access to the African Commission always has allowed and still allows that submission by such entities or individuals against Rwanda may potentially reach the Court (albeit via the African Commission). A contributing factor to Rwanda's withdrawal may (rather) have been that the government did not foresee the submission of six cases against it, within a relatively short period, all dealing with politically sensitive matters, submitted by political opponents of the current government. ${ }^{17}$

Even if all but one (or 88 per cent) ${ }^{18}$ of the cases decided on their substance (admissibility and merits) up to the end of 2016 have reached the Court in this way, they constitute only a handful of cases. Seven direct-access cases have

13 Vienna Conventions on the Law of Treaties, art 56(2) (by analogous reasoning, also applicable to unilateral declarations to treaties) requiring a one-year notice period of denunciation or withdrawal from a treaty.

14 By the end of 2016, no new cases had been submitted to the Court; however, just before 1 March 2017, a number of cases were submitted. $\quad{ }_{15}$ For the State's withdrawal, see $<$ http:// www.chr.up.ac.za/index.php/centre-news-a-events-2016/1604-report-rwandas-withdrawal-of-itsacceptance-of-direct-individual-access-to-the-african-human-rights-court.html>.

${ }^{16}$ See Kayumba Nyamwasa \& others $v$ Rwanda, App 16/2015 (dealing with the amendment of art 101 of the Constitution of Rwanda, which provided that a presidential term is for seven years, renewable only once); see the case summary $<$ http://en.african-court.org/images/Cases/Case $\%$ 20Summaries/KAYUMBA\%20NYAMWASA \%20\&\%20OTHERS $\% 20 \mathrm{~V} . \% 20$ REPUBLIC $\%$ 20OF\%20RWANDA.pdf>.

17 See eg (dealing with her conviction and sentence to 15 years for the crimes of spreading ideology of genocide, abetting terrorism, undermining State security, spreading rumours which may incite the population against political authorities, attempted recourse to terrorism and the establishment of an armed branch of a rebel movement); and Kennedy Gihana \& others $v$ Rwanda, App 17/2015 (dealing with the cancellation of passports of Rwanda nationals abroad); Laurent Munyandilikirwa $v$ Rwanda, App 23/2015 (dealing with the State's recognition of and support for the illegal ouster of the president of a Rwandese NGO, the Rwandan League for the Promotion and Defense of Human Rights (LIPRODHOR), allegedly for being critical of the government).

18 That is, seven out of eight cases. 
been decided on the merits: Mtikila v Tanzania; ${ }^{19}$ Zongo v Burkina Faso; ${ }^{20}$ Konaté v Burkina Faso; ${ }^{21}$ Thomas v Tanzania; ${ }^{22}$ Onyango v Tanzania ${ }^{23}$ Abubakari $v$ Tanzania; ${ }^{24}$ and Actions pour la Protection des Droits de l'Homme (APDH) v Côte d'Ivoire. ${ }^{25}$ The Court has only taken one further merits decision, based on a referral by the African Commission after noncompliance with its provisional measure: the case of African Commission (Saif Al-Islam Kadhafi) v Libya. ${ }^{26}$ In three other cases, the Court decided that it had jurisdiction, but declared the matter inadmissible.

This limited number of direct-access cases decided on matters of substance are principally due to the fact that during the first decade of its existence, the Court in a majority of cases found that it lacked jurisdiction-mostly owing to the respondent States not having made the required declaration under Article 34(6). In the five-year period between 2008 (when the first case was submitted to the Court) and 2012, 11 out of a total of 22 cases were submitted against States that had not become party to the Court Protocol, or that had not made this declaration. Cases failed on this basis against the following States: Algeria, ${ }^{27}$ Cameroon, ${ }^{28}$ Côte d'Ivoire, ${ }^{29}$ Gabon, ${ }^{30}$ Mozambique, ${ }^{31}$ Nigeria, ${ }^{32}$ Senegal, ${ }^{33}$ South Africa (two cases), ${ }^{34}$ Sudan $^{35}$ and Tunisia. ${ }^{36}$ In a further case, the Court found that it lacked jurisdiction because the case was submitted against the $\mathrm{AU}^{37}$ and Morocco, ${ }^{38}$ then a non-AU member State and thus not competent to either ratify the Court Protocol or to make an Article 34(6) declaration. While all these cases were decided on the basis of the Court' lack of personal

19 Mtikila v Tanzania, App 11/2011, Judgment on Merits (14 June 2013).

20 Zongo v Burkina Faso, App 3/2011, Judgment on Merits (28 March 2014).

21 Konate v Burkina Faso, App 4/2013, Judgment on Merits (5 December 2014).

22 Thomas v Tanzania, App 5/2013, Judgment on Merits (20 November 2015).

23 Onyango Nganyi v Tanzania, App 6/2013, Judgment on Merits (18 March 2016).

24 Abubakari v Tanzania, App 7/2013, Judgment on Merits (3 June 2016).

25 Actions pour la Protection des Droits de l'Homme (APDH) v Côte d'Ivoire App 1/2014, Judgment on Merits (18 November 2016).

26 African Commission (Saif Al-Islam Kadhafi) v Libya, App 2/2013, Judgment on Merits (3 June 2015). See also the Court's 2017 decision in African Commission v Kenya (Ogiek), App 6/ 2012 (26 May 2017) (finding Kenya in violation of various provisions of the African Charter); in respect of a matter in which the Commission had issued interim measures.

27 Soufiane Ababou v People's Democratic Republic of Algeria, App 2/2011.

28 Ekollo v Cameroon and Nigeria, App 8/2011.

29 Association Juristes d'Afrique pour la Bonne Gouvernance v Cete d'Ivoire App 2011. Côte d'Ivoire subsequently made the declaration.

30 National Convention of Teachers Trade Union v Gabon, App 12/2011.

31 Daniel Amare and Mulugeta Amare v Mozambique and Mozambique Airlines, App 5/2011.

32 Ekollo M. Alexandre v Cameroon and Nigeria, App 8/2011.

33 Michelot Yogogombaye v Senegal, App 1/2008.

34 Delta International investments (SA), AGL De Lange and M. De Lange v South Africa, App 2/ 2012, as well as Emmanuel Joseph Uko and others v South Africa, App 4/2012.

35 Amir Adam Timan v the Republic of Sudan, App 5/2012.

36 Baghdadi Ali Mahmoudi v Tunisia, App 7/2012.

37 Femi Falana $v$ the African Union, App 1/2011.

38 Ababou v Morocco, App 7/2011, Decision (2 September 2011). 
jurisdiction (jurisdiction ratione personae), one further case, dealing with an AU staff dispute, was decided on the basis of the lack of material jurisdiction (jurisdiction ratione materiae). ${ }^{39}$

This data represents a rather bleak picture: no fewer than 55 per cent of the cases submitted in the first five years have been submitted manifestly without any legal basis. ${ }^{40}$ A cursory reading of the Court Protocol and the available literature should have made it clear to applicants or their lawyers that approaching the Court directly in these cases would have no prospect of success. Either these cases were brought by lay persons without legal counsel, or on the advice of extremely uninformed or unprofessional lawyers, or the cases were submitted to draw attention to a cause, despite awareness of the weak prospects of success. ${ }^{41}$ Regrettably, the African Court did not dismiss these misplaced attempts at accessing the Court with the disrespect they deserved, for example, through a curt letter from the Registrar indicating that the case does not meet the threshold for consideration. ${ }^{42}$ Instead, the Court wasted valuable hours on elaborating lengthy and largely irrelevant judgments in a number of these cases - particularly in the first of this series of cases, Yogogombaye $v$ Senegal, which took just about a year to be resolved. ${ }^{43}$ By including all these 'cases' among its list of 'finalized' cases on its website, the Court does not separate the chaff (of baseless submissions) from the wheat (of validly submitted cases), thus obfuscating the extent of individuals meaningfully accessing the Court. The Court would do better to clarify the distinction between direct and indirect access, and to explain the relevance of Article 34(6) declarations prominently and in accessible language on its website. As far as civil society and lawyers around the continent are concerned, consistently user-friendly accessible information is likely to have a greater effect to inform the relevant public about the basics of accessing the Court than occasional ad hoc visits to selected countries. ${ }^{44}$

Even including these baseless attempts, only 87 cases (including the seven cases decided on the merits) were submitted to the Court in respect of the eight States that have accepted direct access. The total number of directly submitted cases up to the end of 2016 was as follows:

39 Efua Mbonzo'o Samuel v Pan-African Parliament, App 10/2011.

4011 out of 22 cases.

41 Arguably, the latter possibility was in play in the Yogogombaye case, which was submitted to contest the contest the validity of efforts within Senegal to prosecute deposed Chadian dictator Hissène Habré.

42 See the dissenting opinion of Ouguergouz $\mathrm{J}$ in numerous cases, to this effect.

43 This application reached the Court on 29 December 2008 (after having been submitted initially to the AU Commission on 11 August 2008); it was concluded only on 15 December 2009.

44 See eg the extensive coverage in the Court's reports on promotional activities, generally, and sensitization visits, specifically (see eg Report of the Activities of the African Court on Human and Peoples' Rights (2012) AU Doc EX.CL/783(XXII), adopted by the Executive Council in January 2013). By the end of 2016, this was the most recent report of the Court's activities available on its website. 
Tanzania 71, Rwanda 6, Mali 4, Côte d'Ivoire 3, Burkina Faso 2, Malawi 1.

The relative abundance of cases against Tanzania seems to have been generated by the confluence of at least five factors, which are discussed below. Although a comprehensive link between cause and effect is not established here, the argument is that the available evidence cumulatively suggests a strong correlation between these factors and the increase of cases submitted against Tanzania. (1) Having made the Article 34(6) declaration in 2010, Tanzania is one of the earliest countries to have allowed direct access. The possibility of directly approaching the Court had by the end of 2016 been available for six years. (2) With its seat located in Arusha, Tanzania, the Court is in closer proximity to Tanzanians (living in Tanzania) than other direct-access States that are at a greater distance from its seat, with - to some extent- the exception of Rwanda. The seat's location gives more local prominence to the Court's existence, activities and insight into the possibilities it offers. As the seat for the now defunct International Criminal Tribunal for Rwanda, and the East African Court of Justice, ${ }^{45}$ Arusha has been called the 'Geneva of Africa', and can lay claim to being Africa's judicial capital. These factors have contributed to raise the profile of the Court generally, and arguably also in the eyes of Tanzanians. (3) A prominent Tanzanian Judge, Judge Ramadhani, served as the Court's President from 2014 to 2016. Judge Ramadhani, whose term on the African Court stretched from 2010 to 2016, was previously the Chief Justice of Tanzania (from 2007 to 2010), and also served as a Judge on the East African Court of Justice (from 2007 to 2010). (4) Most importantly, however, is the trigger effect of decided cases, which inspired the opening of the 'floodgates' to similar complaints being submitted by others in the aftermath of three cases, all dealing with the fair trial rights and brought by prisoners (the Thomas case (decided in November 2015), the Onyango case (decided in March 2016), and the Abubakari case (decided in June 2016). This led to a noticeable surge in the submission of cases. Two cases were submitted against Tanzania yearly, in 2011, 2012 and 2013; in 2015, the number of submitted cases grew to 26; and in 2016 the number jumped to 40 . The 2015 and 2016 cases almost exclusively relate to fair trial rights, and are brought by inmates of prisons, often following a similar pro forma-type style in their submitted applications. (5) A factor linked to the greater knowledge and visibility of the African Court in Tanzania, generally, and among a particular category (prisoners under sentence of death), specifically, is the issuance of provisional measures in respect of a number of

45 While the EAC Court of Justice is also located in Arusha (and thus in close proximity), whose jurisdiction Tanzania has also accepted, and while this Court also allows for individual access, it lacks an unequivocal substantive basis on which human rights allegations may be based. Notwithstanding, the Court has exercised a human rights-based jurisdiction, and is set to do so more clearly, based on the African Charter, subsequently, in the decision of Democratic Party $v$ Rwanda. 
cases pending before the Court. In nine cases directly instituted before the Court, but by the end of 2016 still awaiting a hearing on the merits, the Court ordered that Tanzania refrain from executing the death penalty. ${ }^{46}$ What makes these cases remarkable is that the State is required to refrain from executing the applicants in cases in which the trial court imposed the death penalty. In a society where popular and political majorities resoundingly support the death penalty, any media attention to this issue would spur much interest.

Five reasons for the relative lack of direct access cases are now considered.

\section{The very existence of Article 34(6) as an impediment}

In Falana $v A U,{ }^{47}$ the Court had the opportunity to consider whether the very existence of optional direct access, as embodied in the requirement to make an Article 34(6) declaration, violates the African Charter or other human rights treaties. The applicant argued that Article 34(6) - and the failure of Nigeria to make such a declaration - violates the African Charter's provision on the right to be heard (as part of Article 7, the right to a fair trial). Put another way, the question before the Court was whether the AU can be held responsible (for having violated the Charter) by virtue of an act or omission (the adoption of the Protocol containing the provision; or the failure to make an Article 34(6) declaration) of one of its member States (Nigeria)). An ancillary question is whether the AU, as an international organization committed to uphold human rights and even to intervene in members under certain circumstances, can compel its members to take certain action (such as making an Article 34(6) declaration) or refrain from certain action (such as adopting Article 34(6) as part of its treaty regime). In the view of the majority of the Court, the answer is quite evident: on the basis that this matter was instituted against the $\mathrm{AU},{ }^{48}$ which is not in its own right a State party to the Court Protocol, and cannot become one, the majority found that the Court lacked personal jurisdiction. The adoption of Article 34(6) was a decision of a majority of States; and the failure to make a declaration was a sovereign act by the Nigerian government. It seems that answer is clearly correct: as an autonomous international organisation, the AU has legal personality separate and distinct from its members. ${ }^{49}$ The AU can only become responsible for the acts or omissions of its organs or agents. As such an entity, it did not accrue obligations, in that it is not a State party to the African Charter. On the basis

\footnotetext{
46 See eg Guehi v Tanzania, App 1/2015, Order for Provisional Measures (18 March 2016); and Rajabu and 4 others $v$ Tanzania, App 7/2015, Order for Provisional Measures (8 March 2016).

47 Falana v African Union, App 1/2011, Judgment (26 June 2012).

48 Falana v African Union, App 1/2011, Judgment (26 June 2012); see also Atemnkeng v African Union, App 14/2011.

49 See eg A Kilangi, 'Legal Personality, Responsibility and Immunity of the African Union: Reflection on the Decision of the African Court on Human and Peoples' Rights in the Femi Falana case' (2013) 1 AUCIL Journal of International Law: A Journal of International Law of the African Union Commission on International Law 95.
} 
that it lacked jurisdiction, the majority held that it did not have to deal with the substantive issue before it.

Coming to a different conclusion on jurisdiction, a minority of four judges postulated the attractive proposition that the optional nature of direct access deprived many Africans from recognition of their right of access to justice. ${ }^{50}$ In the minority's view, because this right is recognized in the Charter, in other treaties and in fact is part of jus cogens, the mere act by the AU member States of imposing the requirement of Article 34(6) in the Court Protocol is a violation of this norm.

Attractive as this line of thinking may seem from a pro homine perspective, it takes one along a very shaky legal route. It disregards the role of consent as the basis of international (human rights) law. An obvious retort is that there could hardly be an internationally accepted legal obligation on AU member States to adopt a human rights treaty allowing for direct individual access to the Court, if only one such treaty (the European Convention, since 1998 allowing direct access to the European Court) exists in the world today. The only other comparable regional human rights system, the Inter-American, indeed only has a system of (optional) indirect access to its judicial institution, the InterAmerican Court. An argument that emphasizes State consent finds support in the decision on Rwanda's withdrawal of its optional declaration under Article 34(6), in which the Court declared: 'As far as unilateral acts are concerned, state sovereignty commands that states are free to commit themselves and that they retain discretion to withdraw their commitments.' ${ }^{51}$ Ultimately, it seems that only a process of amending the Protocol, by decision of the AU Assembly of Heads of State and Government, could achieve the result the applicant (Femi Falana) desired. ${ }^{52}$

\section{The small number of States accepting direct access}

The small number of declarations under Article 34(6) - only eight so far, with Rwanda's withdrawal taking effect on 1 March 2017, thus reducing the number to seven-is an important factor. However, this factor is not conclusive to permitting actual access. That an Article 34(6) declaration is a necessary but insufficient condition for direct access to the Court may be seen from the fact that no cases have been instituted against some of the States that were among the first to make such a declaration. Ghana had, for example, deposited its ationation already in $201 \theta_{2}$ but no application against it has been submitted

50 Falana v African Union, App 1/2011, Dissenting Opinion (Akuffo VP, Ngoepe, Thompson JJ) (26 June 2012) (Falana Dissenting Opinion). Two Judges (Mutsinzi and Ouguergouz JJ) wrote separate opinions in this matter, agreeing with the majority, but for different reasons.

51 Withdrawal, para 58.

52 Court Protocol, art 35; see also also the call of the dissenters 'that the problems raised by Article 34(6) will receive appropriate attention' (Falana Dissenting Opinion, para 17). 
to the Court over the subsequent six years. Also, very few cases against Ghana have ever been submitted to the African Commission. ${ }^{53}$

The African Court has made efforts to encourage an increase in Article 34(6) declarations by way of sensitization visits to States that have not yet made the declaration. Logic suggests that the member States of the Economic Community of West African States (ECOWAS) are most likely to make these declarations. These States all already accept, by virtue of their membership of ECOWAS, the jurisdiction of the ECOWAS Community Court of Justice. This Court not only has jurisdiction over human rights, as set out in the African Charter, but also allows direct access - even without requiring the exhaustion of domestic remedies. ${ }^{54}$ Allowing such ease of access to a subregional court, while at the same time denying direct access (after the exhaustion of domestic remedies) on the same substantive basis at the regional level, seems to present a clear anomaly. This anomaly is rooted in actual practice, with the ECOWAS Court having been 'at least as active in adjudicating human rights violations' as the African Court and Commission. ${ }^{55}$ It should therefore come as little surprise to note that five ECOWAS member States (Benin, Burkina Faso, Côte d'Ivoire, Ghana and Mali) have rid their legal systems of this anomaly (and thus make up the core of the seven direct-access States). While it is disappointing and incongruous that almost half the ECOWAS member States have not even ratified the Court Protocol, ${ }^{56}$ the most compelling argument for making the Article 34(6) declaration, at present, should be directed at those ECOWAS member States that are party to the Court Protocol and had not yet done so: The Gambia (in particular in the Adama Barrow era), Niger, Nigeria and Senegal. Clearly, two of the hegemons in West Africa, Nigeria, in the anglophone and Senegal, in the francophone parts of the subregion, have thus far refrained from accepting direct access to the continental Court. Is it possible that Senegal has been made watchful due to the submission of the Yogogombaye case; and that Nigeria is more inclined towards the ECOWAS Court, for which it provides the seat in its capital, Abuja? In any event, these two States are in the company of other subregional hegemons (South Africa in Southern Africa; and Kenya in East Africa) that are party to the Court Protocol but have not made Article 34(6) declarations. Is a tendency of hegemon-exceptionalism emerging, similar to that in the Inter-American system, where the USA and Canada are not party

\footnotetext{
53 The African Commission has only ever found a violation against Ghana in one communication (Comm 103/93); four other complaints have been declared inadmissible; one complaint had been withdrawn.

54 ST Ebobrah, 'A Rights-Protection Goldmine or a Waiting Volcanic Eruption? Competence of, and Access to, the Human Rights Jurisdiction of the ECOWAS Community Court of Justice' (2007) 7 AHRLJ 307 325-8.

55 KJ Alter, LR Helfer and JR McAllister 'A New International Human rights Court for West Africa: The ECOWAS Community Court of Justice' (2013) 107 AJIL 737.

56 They are: Cape Verde, Equatorial Guinea, Guinea-Bissau, Guinea, Liberia, Sierra Leone and São Tomé e Principe.
} 
to the main treaty of the Organisation of American States (OAS), the American Convention of Human Rights, and do not accept the jurisdiction of the American Court of Human Rights?

The same argument can, to a slightly less forceful extent, be made in respect of member States of the East African Community (EAC), where a subregional court of justice, allowing for direct access, is also in place. Direct supranational access, without exhausting domestic remedies, is also possible from EAC member States to the East African Court of Justice. Although the Court does not have the jurisdiction to find violations of human rights, as such, and thus also not of the African Charter, the Court has found violations of the EAC Treaty even when the findings (also) entail human rights violations. This aspect of the EAC Court's jurisdiction has on numerous occasions been explored by human rights actors, leading to decisions with human rights ramifications in respect of all five member States. ${ }^{57}$ In the 2015 Democratic Party judgment, ${ }^{58}$ the EAC Court's Appellate Division specifically clarified that it has jurisdiction to interpret the African Charter as part of establishing States' adherence to their commitment under the EAC Treaty related to human rights, including the African Charter. ${ }^{59}$ The EAC Court differs from the ECOWAS Court in that, while the ECOWAS Court has been accorded substantive jurisdiction over the African Charter, the EAC Court lacks explicit human rights jurisdiction. All five EAC members have ratified the African Court Protocol, but only two have made declarations accepting direct access to the African Court. ${ }^{60}$ One of these States, Rwanda, subsequently withdrew its declaration. Rwanda's initial declaration (on 22 January 2013) came amidst a case having been instituted against EAC member States, in which it was contended that the failure to accept direct access to the African Court violated both the EAC Treaty and African Charter. ${ }^{61}$ Considering the

\footnotetext{
57 See JT Gathii, 'Variation in the Use of Supranational Integration Courts between Business and Human Rights Actors: The Case of the East African Court of Justice' (2016) 79 LCP 37. However, the introduction of an Appellate Division, and procedural limitations have detracted from the Court's impact, see EAC Court Appellate Division (Appeal 1/2011, Attorney General of Kenya $v$ Independent Medico Legal Unit, Judgment of 15 March 2012), on appeal, the matter was struck out for not having been filed within the time limit of two months of the action or decision complained of, as prescribed under art 30(2) of the EAC Treaty. However, the EAC Court Appellate Division (Appeal 1/2012, Attorney General of Rwanda v Plaxeda Rugumba Judgment of June 2012), on another occasion confirmed that the 2-month period does not apply when it is unclear when information was provided about the situation of a person who is held incommunicado.

58 EAC Court Appellate Division, Democratic Party $v$ Secretary-General EAC and Others, Appeal 1/2014 (28 July 2015) (Democratic Party case).

59 See Democratic Party case, eg para 73: 'the East African Court of Justice has the jurisdiction to interpret the Charter in the context of the Treaty'; and para 71: 'In as far as ... Article 6(d) recognize the Charter's relevance in promotion and protection of human and peoples' rights, then compliance with those provisions of the Charter become, ipso jure, an obligation imposed upon the Partner States under the Treaty.'

60 South Sudan, which had joined the EAC in 2016, has not ratified the African Court Protocol.

61 Democratic Party $r$ Secrenty Genal EAC and Others, Appeal 1/2014 (28 July 2015): see, para 78 of the judgment: 'We remind ourselves that at the Scheduling Conference of the Appellate Division, the Appellant abandoned the issue of costs against the Republic of Rwanda, which had
} 
sequence of events, it appears that Rwanda made the declaration primarily to avert an adverse judicial finding. Having resulted from extraneous forces and not from a process of domestic deliberation and participation, Rwanda's withdrawal could thus be undone without much domestic political cost.

\section{The exhaustion of domestic remedies requirement}

It is an undeniable reality that many potential disputes could have made their way to the African Court, but did not. The reasons for cases not being submitted to the African Court relate to three layers of obstacles. The first is the requirement that the aggrieved person should conceive of what 'happened to them' as a 'human rights violation'. Put differently, the grievance has to be crystallized into a judicialized dispute. However, this does not come intuitively to many in Africa, where the existence of a legal culture (a culture rooted in the rule of law), often remains underdeveloped and illusory. At the domestic level, only a fraction of potential 'injurious experiences' ever end up as formally litigated claims. ${ }^{62}$ To explain the limited extent to which legal disputes are crystallized from a much larger universe of invisible, unquantifiable lower layer of 'proto-disputes', ${ }^{63}$ socio-legal scholars developed the notion of the 'dispute pyramid'. ${ }^{64}$ In most of Africa, including the direct-access States, the likelihood of a sociological 'problem' being conceptualized as a 'legal dispute' is remote. By far the greatest number of potential human rights 'cases' therefore fail to ever percolate into a matter of legal concern. The second layer of obstacles relates to domestic judicial systems. Even if the matter is conceived of as a potential 'legal dispute', the aggrieved person may never access a lawyer or the court system, owing to the limited geographic spread of lawyers and courts especially in rural areas; and the prohibitive cost involved in travel and legal fees. Even if the aggrieved person manages to have the case proceed to court, access to justice may remain illusory - enter a third layer of obstacles - due to the operation of the system itself, characterized by structural deficiencies such as the long delays in finalizing cases, other institutional inefficiencies, and corruption.

\section{Awareness about and capacity for approaching the Court}

The available evidence (including the erroneous submission of cases directly to the Court, and the Court's own efforts to raise awareness about itself within

deposited its declaration while the Reference was still pending before the First Instance Division' (emphasis added).

${ }^{62}$ M Galanter, 'Reading the Landscape of Disputes: What We Know and Don't Know (and Think We Know) about Our Allegedly Contentious and Litigious Society' (1983) 31 UCLA Law Review 4, 12.

63 WLF Felstiner, RL Abel and A Sarat, 'The Emergence and Transformation of Disputes: Naming, Blaming, Claiming ...' (1980-81) 15 Law\&SocyRev 631, 632.

64 Galanter (n 62); Felstiner Abel and Sarat ibid. 
African States) suggests that his is an important constraining factor. Of the cases that are actually finalized in the domestic judicial system, some cases may end in a finding unfavourable to the aggrieved party and would thus be 'eligible' for submission to the Court. However, even these cases may never reach the Court because both the aggrieved person and the domestic lawyers may not be aware of or alert to this possibility, and the lawyer may lack the knowledge and capacity to take on the case. It is only in respect of the cases found in the aggrieved person's favour where there is no need for access to internationalized justice. Regrettably, these cases may be few and far between.

5. The requirement for an NGO under Article 34(6) to enjoy 'observer status' with the African Commission

Although this requirement may appear burdensome, it has not proved to be an actual inhibitor to access, as the 'individual' category is broad and open-ended enough to facilitate the role of NGOs in the process-even if they do not have the required 'observer' status.

\section{B. Indirect Access via African Commission}

The indirect road to the Court, via the African Commission, takes four possible routes, which are set out in Rule 118 of the Commission's Rules of Procedure. These different avenues do not, however, present clear-cut or divergent courses, but may sometimes overlap or run concurrently.

\section{The road not (yet) taken: The Commission referring its unimplemented merits finding to the Court}

The African Commission's competence to refer to the Court cases decided by the Commission on the merits is explicitly provided for in Rule 118(1) of its Rules of Procedure. This form of referral concretizes the role of the Court of 'complementing' the Commission's protective mandate by providing for an unequivocally legally binding decision in instances where the State concerned does not abide by a recommendatory finding of a quasi-judicial body. The trigger for this referral is twofold: non-compliance by the respondent State, as determined by the Commission; and the exercise of the Commission's discretion in favour of referral.

Resembling the Inter-American system and the erstwhile European Commission/Court relationship, the Court's role in a Rule 118(1) referral may be viewed as that of 'converting' the Commission's non-binding finding into a binding decision. Recognizing that one of the main reasons for referral of cases to the Court is the non-compliance by a respondent State with the Commission's finding, the Commission's Rules of Procedure mandate it to

refer a case to the Court when a State did not or is unwilling to take effective 
measures to give effect to the finding, within six months of being notified of the finding. 65

While non-compliance seems to be the trigger for this form of indirect referral by the Commission to the Court, this factor in itself does not guarantee referral, since the Commission retains the discretion to refer (or not to refer) such cases. ${ }^{66}$ The question is: what other factors would or should guide the exercise of this discretion? Taking a leaf from the Inter-American Commission's Rules, ${ }^{67}$ the view of the complainant about the desirability of referral, and the 'nature and seriousness of the violation', seem to be important factors to take into account. However, Rule 45(1) of the Rules of Procedure of the Inter-American Commission stipulates that the Commission 'shall refer the case to the Court, unless there is a reasoned decision by an absolute majority of the members of the Commission to the contrary' (emphasis added). The above-mentioned factors (in respect of the InterAmerican system) are thus taken into account only to rebut a presumption of referral. ${ }^{68}$ The factors that should influence the Commission in the exercise of its discretion could include: the attitude of the State, as reflected in the reasons for and extent of non-compliance by the State; the views of the complainant on the matter; the extent to which there may be a factual dispute (to be resolved by the Court) especially if the complainant was exempted for exhausting local remedies; the nature and seriousness of the violation; the prospect of successfully presenting the case before the Court; and the potential importance of the case for other State parties. ${ }^{69}$

Under the old European system, the European Commission of Human Rights also had the discretion to refer cases to the European Court of Human Rights. With no guidance being provided in either the European Convention or the Rules, the Commission initially referred very few cases to the Court. In the period between 1959 (when the European Court was established) and 1968, for example, the Commission only referred two out of 49 potential cases to the Court. ${ }^{70}$ Later, a change of heart ensued, and referral became more common, culminating in a practice of universal referral. In 1998, this duality disappeared, when the European Commission ceased to exist. ${ }^{71}$

\footnotetext{
65 Rules 112(2) and 118(1) of the Commission's 2010 Rules of Procedure. The period may be prolonged: Rule 112(3) and 118(4). The vague formulation of these Rules leaves the period of further delay indeterminate. 66 Rule 118(1), 2010 Rules of Procedure.

67 Rule 45, Rules of Procedure of the Inter-American Commission.

68 Rule 45(1) of the Rules of Procedure of the Inter-American Commission; the Commission 'shall refer the case to the Court, unless there is a reasoned decision by an absolute majority of the members of the Commission to the contrary'.

69 Other factors, such as the need to 'develop or clarify' the existing case-law, which are considerations under the Inter-American system, are at this stage of lesser concern in an African context, given the dearth of cases and the limited jurisprudence.

70 E Bates, The Evolution of the European Convention on Human Rights; From Its Inception to the Creation of a Permanent Court of Human Rights (Oxford University Press 2010) App 3.

71 Protocol 11 to the European Convention, which created a single permanent judicial institution, entered into force in 1998.
} 
It is suggested strongly that the African Commission should pre-empt the stages through which both the European and Inter-American systems evolved, by adopting the logical end-point, namely, a presumption that all cases of established non-compliance are referred to the Court, unless a majority of the Commission's members decide otherwise on a substantiated basis mainly informed by the views of the complainant.

By the end of 2016, the African Commission has not referred any case on the basis of Rule 118(1), that is, after deciding the case on the merits. Some pertinent reasons for the dearth in referral are now scrutinized.

Importantly, the Commission can only refer cases against parties to the Protocol. This factor further explains why there have been very few candidates for this form of referral: Commission has found violations between 2010 (when its current Rules of Procedure entered into force) and 2016, such as Angola, DRC, Ethiopia, Eritrea, Sudan and Zimbabwe, have over that period not accepted the jurisdiction of the Court. An additional factor limiting the pool of potential cases is the inability of the Commission to finalize more than a very small number of cases over this period.

But even where it had been possible, the Commission had been reluctant to make referrals. One of the primary candidates for referral is the Endorois case (Centre for Minority Rights Development v Kenya). ${ }^{72}$ The Commission decided this case on the merits as far back as November 2009, finding Kenya in violation of various rights of the Endorois people resulting from the community's forcible displacement from their ancestral land, without proper consultation or compensation, in order to establish a game reserve and stimulate tourism. The reasons for non-referral may have a factual and legal basis. As for the factual dimension, the issue is establishing actual 'non-compliance'. As this case vividly illustrates, 'compliance' is not a zero sum game, but needs to be established along a complex continuum where political will to give effect to the decision may appear, disappear and reappear. Applying rules inflexibly may not be the most appropriate way of dealing with a dynamic political context, where political willingness is constrained by the polycentric nature of the indigenous peoples' claim to land. At the same time, the latitude allowed to a non-implementing State should be restricted by an outer limit, which is not the case at present. Responding to the State's procrastination, the Commission broke new ground in its fledgling follow-up practice by holding an implementation hearing, involving the parties, ${ }^{73}$ and by taking a resolution to urge the Kenyan government to report on its implementation of

72 (2009) AHRLR 75 (ACHPR 2009).

73 Held at the Commission's 53rd Ordinary Session, 9 to 23 April 2013, in Banjul, The Gambia. 
the decision. ${ }^{74}$ However, by the end of 2016, the case has not been referred, despite Kenya's lack of full cooperation.

One of the factors constraining Commission-referrals appears to be the apprehension that a case, once referred, will undergo a de novo consideration (with a full reconsideration of the facts and the law, including admissibility, merits and remedial orders). On the understanding that these findings are referred to the Court after determinations both of admissibility and the merits, the question arises how the Court should treat the Commission's findings on these issues. The answer in my view should be informed by purposive and cooperative complementarity, that is, a situation where the two distinct entities work together to enhance their shared purpose (securing the most effective human rights protection), rather than to undermine this purpose (for example, by exacerbating delays, duplication or erosion of confidence) ${ }^{75}$ Legally speaking, and as the evolution of both the European and InterAmerican systems indicates, the Court is competent to fully reconsider the facts and the law. In its very first contentious case, ${ }^{76}$ the Inter-American Court had to answer the Inter-American Commission's contention that the Court 'has a limited jurisdiction that prevents it from reviewing' all aspects of cases referred by the Commission. ${ }^{77}$ The Court rejected this argument, based on the provisions of the Convention granting it competence to decide 'all matters relating to the interpretation or application of (the) Convention' ${ }^{78}$ Similar broad wording in the Court Protocol supports the adoption of a parallel position in the African human rights system. ${ }^{79}$ In the decision, the InterAmerican Court emphasized its role as autonomous and sole judicial interpreter of the Convention. ${ }^{80}$

What is clear is that the prospect of the Court merely rubber-stamping the Commission's findings (that is, simply 'converting' the quasi-judicial findings into binding decisions) is out of the question. But should the Court necessarily reconsider every single aspect of the case before it? In answering this question, a distinction is here drawn between prior Commission decisions on admissibility and merits.

As far as admissibility decisions are concerned, it may be argued that the Court's reconsideration of the decision should as far as possible be

\footnotetext{
74 African Commission Resolution 257, Calling on the Republic of Kenya to Implement the Endorois Decision, adopted on 5 November 213 (non-compliance of the Republic of Kenya with its pledge to transmit an interim report within 90 days of the oral hearing in April 2013, and a comprehensive report to the Commission's session in October/ November 2013).

${ }^{75}$ See also ST Ebobrah, 'Towards a Positive Application of Complementarity in the African Human Rights System: Issues of Functions and Relations' (2011) 22 EJIL 663.

76 I/A Court H.R., Velásquez Rodríguez v Honduras. Preliminary Objections. Judgment of June 26, 1987. Series C No 1. 77 para 28 78 American Convention, art 62(1).

79 Court Protocol, art 35(1) also uses the term 'written request'.

80 para $29 \dot{\bar{x}}_{\mathbf{2}}$ 'In exercising these powers, the Court is not bound by what the Commission may have previously decided; rather, its authority to render judgment is in no way restricted. The Court does not act as a court of review, of appeal or other similar court in its dealings with the Commission.'
} 
minimized. Dealing with admissibility from scratch, as a matter of course, would lead to duplication and delay. Conflicting decisions on admissibility (with the Court finding a matter inadmissible) could fragment the system and undermine purposive and cooperative complementarity. ${ }^{81}$ More fundamentally, the reconsideration of admissibility - especially if it leads to a decision of inadmissibility - could undermine confidence in and delegitimize the entire system. Consider the impact on the perception of this process if, after a protracted process of exhausting remedies in domestic courts and obtaining an admissibility finding from the African Commission, an applicant is - years later - made to stumble at this procedural hurdle before the Court. It is not unimaginable that the entire period to get to the Court's judgment could take longer than a decade. To pre-empt such concerns, the Court should adopt a practice of presuming admissibility in cases brought to it by the Commission. Certainly, a State should be estopped from introducing before the Court inadmissibility arguments not previously raised before the Commission. ${ }^{82}$ It is significant that the 'old' European Court for the first time found inadmissible a case submitted to it by the erstwhile European Commission only in $1980 .{ }^{83}$ However, for such an approach to take root, the African Commission should improve its fact finding and the legal reasoning in arriving at findings on admissibility.

As far as the Commission's findings on the merits are concerned, the Court should be allowed more leeway, while arguably taking as its starting point the factual basis as reflected in the Commission's finding ('report') before it. The Rules of Court seem to follow the suggested approach by allowing the Court to obtain any evidence 'which in its opinion may provide clarification of the facts of the case'. ${ }^{84}$ The Court may further require evidence 'on any specific point', ${ }^{85}$ and may assign one or more Judges to conduct a fact-finding mission. ${ }^{86}$ Particularly where domestic remedies had been exhausted, when both parties were present, contributed to and contested the Commission's factual finding, or when the Commission had in fact conducted a fact-finding mission, it would be inappropriate for the Court to establish the facts afresh.

In any event, as soon as the State starts contesting the facts found by the Commission, the absence before the Court of the initial complainant becomes intolerable. One clear conclusion to be drawn is that, if the Court reopens

81 See the separate opinion of Judge Trinidade in the Castillo-Páez v Peru. Preliminary Objections. Judgment (30 January 1996) para 10: 'The principal concern of both the Court and the Commission should lie, not in the zealous internal distribution of attributions and competences in the jurisdictional mechanism of the American Convention, but rather in the adequate coordination between the two organs of international supervision so as to assure the most effective protection possible of the guaranteed human rights.'

${ }^{82}$ Inter-American Court of Human Rights, Gangaram Panday v Suriname, Preliminary Objections, 4 December 1991, Ser. C 12, para 40.

83 The Van Oosterwijck case, decided on 6 November 1980, Series A 40 (1981).

84 Rule 44(1) of Rules of Court.

${ }^{85}$ Rule 44(2) of the Rules of Court.

86 Rule 44(3) of the Rules of Court. 
questions of fact, the complainant must have a voice at the table at which this issue is debated. ${ }^{87}$

\section{The Commission referring its unimplemented interim measure to the Court}

Rule 118(2) presents a variant to the Rule 118(1) access, as it allows the Commission to refer its unimplemented 'requests' for interim measures to the Court, for its binding orders on provisional measures. The importance of getting the Court involved in these findings is exhibited in the disregard by States for some of the Commission's interim measures requests. ${ }^{88}$ The difference between this and the first category of referral is that, here, the case has not been considered on its merits. Indeed, both the Commission and the Court have emphasized in their practice that a request or order for provisional measures does not prejudge the outcome of the substantive issue. ${ }^{89}$ Once the case has been referred to the Court, the case is no longer before the Commission; there is thus no parallel ongoing process. ${ }^{90}$

The question may be posed whether the Commission can issue such a request only once it has declared the communication admissible. In line with the InterAmerican precedent in this regard, the Commission's provisional measures request should not be made to depend on the admissibility of the matter before it. In a communication concerning the harassment of a candidate for the August 2012 elections in Angola, the Commission made its request without having found the matter admissible. ${ }^{91}$

By the end of 2016, the Commission referred two cases explicitly on the basis of Rule 118(2). One case relates to Saif Al-Islam Ghadafi, son of the erstwhile Libyan leader. Having ordered provisional measures on 18 April 2012, and after in vain allowing a prolonged period to secure State compliance, the Commission referred this case to the Court. The Court ordered provisional measures of its own on 15 March 2013.92 Although some response was forthcoming, the State was found not to have complied with the provisional

\footnotetext{
${ }^{87}$ See the separate opinion of Judge Trinidade in the Case of Castillo-Páez v Peru. Preliminary Objections. Judgment of January 30, 1996, para 15: 'The reopening of such questions before the Court, without the presence of one of the parties (the petitioning plaintiffs), militates against the principle of procedural equality (equality of arms/égalité des armes).' See also the discussion in Section III below.

${ }^{88}$ See eg International Pen and Others (on behalf of Saro-Wiwa) $v$ Nigeria and Interights and Others (on behalf of Bosch) $v$ Botswana.

${ }^{89}$ See eg App 21/2016, Mukwano v Tanzania, Order for Provisional Measure (3 June 2016) para 19

90 Ogiek (n 26) para 74.

91 Mendes v Angola, Comm 413/12 (request for interim measures submitted on 21 April 2012; Commission issued its 'order" on provisional measures on 30 April 2012; and later, on 25 February 2013, issued its finding on admissibility, finding the communication inadmissible).

92 African Commission (Saif Al-Islam Kadhafi) v Lybia, App 2/2013, Order of Provisional Measures (15 March 2013).
} 
measures order. ${ }^{93}$ Although the Commission's referral fits Rule 118(2) (noncompline with a provisional measure), the Court makes little reference to the Commission's request for provisional measures, opting instead to foreground the merits of the case. It also specifies that it adopted its own provisional measures 'of its own accord', as if not prompted by the Commission to do so. However, as Ouguergouz J shows, ${ }^{94}$ the Commission in fact submitted the case on the basis of the State's failure to comply with the initial request for provisional measures.

The second case relates to an indigenous community in Kenya, the Ogiek, which has 'since time immemorial' been living in particular forested areas in the country, including the Mau forest. Having received, on 14 November 2009, a communication concerning the eviction of this community, the Commission acted relatively swiftly, and on 23 November 2009 issued a request for provisional measures to Kenya, to 'stop irreparable harm'. This matter was referred to the Court on 12 July 2012, on the basis of both Rules 118(2) and (3). Some time later, on 15 March 2013, the Court ordered provisional measures. ${ }^{95}$ It has subsequently, in 2017 , concluded the consideration on the merits. ${ }^{96}$

3. Referral of serious or massive human rights violations: based on a situation or a formal communication?

Under Rule 118(3), the Commission may submit a 'case' to the Court if a 'situation' in its view constitutes 'one of serious or massive violations of human rights' ${ }^{97}$ Because the Commission is already entitled, under Rule 118 (4), to refer any communication (also one dealing with 'serious or massive violations') before it 'at any stage of the examination', this Rule could potentially be interpreted as allowing referral of a 'case' based on evidentiary material that does not form part of a 'communication' before the Commission. Such an interpretation would allow for a meaningful distinction between the two sub-Rules, with Rule 118(3) understood as adding an independent, complementary ground for referral not foreseen under Rule 118(4). It would also be the interpretation that allows greater access to the Court (via the Commission). For these reasons, in my view, this interpretation could be adopted.

93 The Court subsequently decided the case on its merits, finding that Libya had violated the fair trial rights of the detainee: African Commission (Saif Al-Islam Gaddafi) v Lybia, App 2/2013, Judgment (3 June 2015).

94 Separate Judgment, para 2.

95 African Commission (Ogiek) v Kenya, App 6/2012, Order for Provisional Measures (15 March 2013).

96 See the Ogiek judgment (n 26) for the request to intervene under Rule of Court 29(3)(c) 'to be heard in the case as original complainants before the Commission' (para 14); the Court's grant of the request (para 27); and reference to the Head of Law, Minority Rights Group, actually being heard by the Court (para 29).

97 Rule 118(3) of the Commission's 2012 Rules of Procedure. 
However, the Commission has not as yet adopted this interpretation. In the Ogiek case, for example, the Commission's referral (of a communication pending before it) makes mention of two Rules, the one allowing for the referral of an unimplemented request for preliminary measures (Rule 118(2)), and the other for referral of a situation of massive violations (Rule 118(3)). Clearly, the Commission could also have invoked Rule 118(4), because this matter constitutes a referral at one of the 'stages' of the 'examination of a communication'.

Viewing Rule 118(4) as an overarching and guiding provision, Rule 118(3) may be regarded as finding application only in respect of communications already pending before the Commission that reveal serious or massive violations. ${ }^{98}$ In this interpretation, Rule $118(3)$ is subsumed under the Rule 118(4), rather than providing for a separate ground for referral.

\section{Referral to substitute the Commission's admissibility and merits finding with that of the Court}

In Rule 118(4), the Commission's Rules take a decisive and unprecedented step towards effective complementarity with the Court by providing that the Commission may 'seize' the Court 'at any stage of the examination of a communication'. 99 To distinguish this possibility from referrals in case of non-compliance, it must be assumed that 'any stage' here means any stage before a decision on the merits has been reached, and before the expiry of the 180-days implementation period granted to the violating state. ${ }^{100}$ If this distinction were not drawn, it would not have been necessary to allow separately (in Rule 118(1)) for referral in cases on non-compliance after a final finding and non-compliance with that finding, because that form of referral would have been covered by 'any stage of the proceedings'. Under Rule 118(4), the Court's role is thus not to refer the Commission's unimplemented finding on the merits, but constitutes the first 'international decision' on the merits of the complaint/case.

If the Commission should apply Rule 118(4) with great regularity and frequency to refer cases to the Court before deciding on the merits of these cases, this avenue may potentially substitute the Commission's protective role with that of the Court. In fact, States may argue that referral by the Commission in such instances amounts to giving individuals direct access to

\footnotetext{
98 This interpretation is, adopting a textual approach, arguably better aligned with art 58(1) of the Charter (which uses the word 'communication'), referred to in Rule 118(3); as well as with Rule $84(2)$, which is referred to in Rule 118(3), which is arguably contextualized by the notion of 'one or more communications' (see rule 84(1)). $\quad{ }_{99}$ Rule 118(4), 2010 Rules of Procedure.

100 Arguably, when the Commission allows a further extension of the implementation period (under Rule 112(2) and (3)), Rule 118(4) would only come into play after the expiry of the further prolonged period. The Commission's consideration of the issue of referral would under those circumstances still fall under Rule 118(1).
} 
the Court, thus rendering redundant States' acceptance of direct access. However, such an argument falters, as it does not account for the fact that referrals under Rule 118(4) are still initiated by the Commission, and not by the aggrieved individuals themselves.

Still, it would be appropriate for the Commission to avoid a practice of routinely referring cases without finalizing them, lest the argument be forwarded that, de facto, such routine referrals nullify the difference between States that have made an Article 34(6) declaration and those that have not. The possibility to refer a case prior to the Commission finalizing it is guided only be the requirement of 'necessity'. ${ }^{101}$ Alert to the need for effective coexistence and reinforcing complementarity, the main consideration here should be the urgency or immediacy of the need for a binding decision. A pertinent example would be a pressing matter requiring urgent resolution, in respect of a State or in a situation where the respondent State is unlikely to comply with the Commission's directive. The Commission should refer such a case to the Court, either without dealing with it at all, or immediately after determining its admissibility. As a general rule, the Commission should not leave it to the Court to determine admissibility in respect of matters that are manifestly inadmissible. This would be an unwise use of resources. In such instances, the Commission should act as a filtering mechanism.

The first case referred by the Commission to the Court arguably falls into the Rule 118(4) category. In the African Commission on Human and Peoples' Rights (Benghazi) v Libya, ${ }^{102}$ the Commission did not mention the specific Rule under which it referred the case. It is, however, clear that the Commission did not decide any aspect of the case prior to referral. Once the case was before it, the Court of its own accord decided to order provisional measures. It could therefore be assumed that the case was based on a communication before it, and that the Commission referred the case before deciding the admissibility of the matter. ${ }^{103}$ Soon after receiving the case, the Court issued an order after concluding that there was a situation of extreme gravity and urgency, ${ }^{104}$ as well as a risk of irreparable harm to persons who are subjected to the application. ${ }^{105}$ Thus, the Court ordered that Libya refrains from human rights violations and report within 15 days. Although an order is not a final decision, it is binding, ${ }^{106}$ and can lead to the international

101 Rule 118(4), 2010 Rules of Procedure.

102 App 4/2011, Order for Provisional Measures (25 March 2011).

103 While this case could arguably also be described as an instance of massive violations referral, this would not be so if Rule 118(3)-referrals only relates to instances of massive violations in which a communication is not pending. $\quad 104$ Protocol, art 27(2); Rules of the Court, Rule 51(1). 105 para 22 of the Order.

106 On the binding nature of the Commission's interim measures, see International Pen and Others (on behalf of Saro-Wiwa) v Nigeria (2000) AHRLR 212 (ACHPR 1998) paras 115-116 (where the Commission calls Nigeria's non-compliance a 'blot' on its legal system, and reiterates that the country is 'legally bound' by the Charter's provisions); see, however, Interights and Others 
responsibility of States. ${ }^{107}$ The case was never finalized on the merits, due to the inability of the African Commission to bring forward and present the case to the Court. ${ }^{108}$

5. Access deferred: The possibility of indirect access via the African Children's Rights Committee

The Court Protocol omits the African Children's Rights Committee from the list of entities in Article 5(1) that are expressly entitled to 'submit' cases to the Court. ${ }^{109}$ No indirect access to the Court, by way of referral by the Committee, is thus possible.

This textual omission creates a threefold anomaly. First, although the Court can find violations of the African Children's Charter in direct-access cases, on the basis of the Court's substantive mandate, ${ }^{110}$ it cannot hear cases alleging violations of the Children's Charter that have been considered by the African Children's Rights Committee. Second, although the Committee has since its establishment in 1999 been exercising a protective mandate procedurally similar to that of the African Commission, and has been beset by the problems very similar to those experienced by the Commission, only the Commission is eligible to refer cases to the Court. Two human rights monitoring bodies, set up under the umbrella of the same intergovernmental organization, therefore operate fundamentally differently: cases before the one (the Commission) can be referred to an independent judicial body, for its binding decision, while cases before the other body (the Committee) are not eligible for referral to the same judicial institution. Third, when it adopted the Protocol on the African Court of Justice and Human Rights in 2008, the AU Assembly added the Committee to the list of entities eligible to refer cases to the to-be-established Court. ${ }^{111}$ The contention that the Committee should be 'read into' the entities that may refer cases to the Court is supported by the likelihood that the to-be-established Court will not become operational in the near future. ${ }^{12}$ As all other relevant circumstances that are now in place would remain so if and when this Protocol would enter into force, or if it

(on behalf of Bosch) v Botswana (2003) AHRLR 55 (ACHPR 2003), where the Commission was much more ambiguous (para 51) about Botswana's obligations under similar circumstances.

107 J Oder, 'The African Court on Human and Peoples' Rights' Order in respect of the Situation in Libya: A Watershed in the Regional Protection of Human Rights?' (2011) 11 AHRLJ 495500.

108 African Commission on Human and Peoples'Rights (Benghazi) v Libya, App 4/2011, Order (15 March 2013).

109 See art 5, Court Protocol. The Committee's own Rules and the Rules of Court also do not contemplate this possibility.

111 See art 30(c) of the Statute of the African Court of Justice and Human Rights.

112 By the end of 2016, only five States out of the required 15 have become party to the Protocol on the African Court of Justice and Human Rights. 
would be replaced by a subsequent protocol, the AU already committed itself to granting the Committee the competence of referral to the Court. ${ }^{113}$

Against this background, it may come as a surprise that the African Court confirmed these anomalies in a 2014 advisory opinion, when the Committee approached it with the question whether it may refer decided cases to the Court. Although the Court referred to the anomalies set out above, it ultimately opted for a textual and originalist approach. ${ }^{114}$ However, a contextual reading of the Protocol opens up a distinctly divergent yet plausible interpretation. In this reading, the silence of the Protocol on this issue can best be understood against the historical background of its adoption. When the Protocol was adopted in 1998, the Committee did not exist, and the prospect of its establishment either seemed remote, ${ }^{115}$ or was not a pertinent consideration at all, given the relative obscurity of the African Children's Charter at the time. It is therefore unsurprising that the Protocol does not contemplate the Court complementing the African Children's Committee's protective mandate. A contextual approach would also take account of the need for better coordination within the African human rights system. Ensuring that the two bodies have equal access to the Court would enhance the coordination, cohesion and integrity of the system as a whole. Only the optimism inspired by the 1990 democratic epoch can explain why the African Children's Charter was not adopted as a protocol to the African Charter, supervised by the African Commission, ${ }^{116}$ but as a separate treaty with its own treaty body, in competition with the already under-resourced African Commission. ${ }^{117}$

Drawing the necessary implications from the Court's advisory opinion, the AU Executive Council in July 2016 called on the Assembly to add the Committee to the list of entities eligible to refer cases to the Court. ${ }^{118}$ Subsequent to this decision, the matter seems to have stalled, apparently on

\footnotetext{
113 This referral would be the same, even if not this Protocol, but a subsequent Protocol (the Protocol of Amendments to the Statute of the African Court of Justice and Human Rights) would enter into force.

114 Advisory Opinion 2/2013, The African Committee of Experts on the Rights and Welfare of the Child on the Standing of the African Committee of Experts on the Rights and Welfare of the Child before the African Court and Human and Peoples' Rights (5 December 2014).

115 The number of ratifications of the African Children's Charter by the end of 1997 stood at nine (out of a total of 15 ratifications required for its entry into force).

116 See also the Women's Rights Protocol, which does not create an additional treaty body, but gives this role to the African Commission and Court.

117 F Viljoen, 'Why South Africa Should Ratify the African Charter on the Rights of the Child' (1999) 116 SALJ 660.

118 EX.CL/Dec.923(XXIX) Decision on the report of the African Committee of experts on the rights and welfare of the child (ACERWC), recommending to the Assembly 'the amendment of Article 5(1) of the Protocol to the African Charter on Human and Peoples' Rights on the Establishment of an African Court on Human and Peoples' Rights (the Court) to include the ACERWC among the entities entitled to submit cases to the Court and REQUESTS the ACEWRC in consultation with the Commission to prepare the amendment and submit it to the STC on Justice and Legal Affairs for consideration during its session scheduled for October 2016'.
} 
the basis that the prescribed process for amendment, set out in Article 35 of the Court Protocol, has not been followed. This approach seems to favour formalism over functionality. While the process for amendment did not start with a 'written request' by a State, as Article 35 stipulates, the substantive requirement of inclusion and participation had been met. Alternatively, the Committee's request may be viewed as a proposition for amendment, as contemplated under Article 35(2) of the Protocol. In any event, the proposed course of action finds a precedent in the amendment of the African Children's Charter to make members of the Committee eligible for reelection, which came about by way of an Assembly decision based on advice by the AU Legal Counsel, ${ }^{119}$ and not through the formally prescribed procedure of treaty amendment. ${ }^{120}$ As the procedure for amendment of the Court Protocol is materially similar to that of the Children's Charter, the same procedure should be followed to add the Committee to the list of eligible entities. Unfortunately, by the end of 2016, the addition of the Committee to Article 5(1) of the Court Protocol had not been achieved.

\section{ACCESS TO VICTIMS AND THEIR REPRESENTATIVES}

When individuals gain direct access to the African Court, they obviously are able to represent themselves (or be represented by a lawyer) during Court proceedings. When the case reaches the Court indirectly, via the African Commission, complainants should have the same access. In those cases, it is the Commission that refers the case, and it is cited as the party before the Court.

In this respect, the evolution of victims' representation before the InterAmerican and European Courts of Human Rights is very illuminating. Even though the American Convention stipulates that only State parties and the Commission 'have the right to submit a case to the Court', 121 the 'alleged victim' soon acquired a prominent role in the proceedings before the Court. From the outset, the Commission allowed the victims and their representatives to be an 'integral part' of the Commission's delegation and to take part in the proceedings before the Court, for example by crossexamining witnesses. ${ }^{122}$ During a public hearing in 1996, one of the Judges took the initiative and started addressing questions pertaining to reparations

119 Assembly/AU/Draft/Dec.528(XXIII), Decision on the Report of the African Committee of Experts on the Rights and Welfare of the Child, in which the inclusion of the phrase 'and may be re-elected only once' is added to art 37(1) of the Charter. The Assembly requested the AU Commission to notify all States Parties of the amendment and 'to present the amendment for adoption during the January 2015 Summit in conformity with the provisions of Article 48(1) of the African Charter on the Rights and Welfare of the Child'.

120 African Children's Charter, art 48(1) stipulates that the Charter may be amended 'if any state party makes a written request to that effect'. $\quad{ }^{121}$ Art 61(1) of the American Convention.

122 For a comprehensive view on this evolution, see L Burgorgue-Larsen and A Úbeda de Torres, The Inter-American Court of Human Rights: Case Law and Commentary (Oxford University Press 2011) 40-7. 
to the victim's representatives. ${ }^{123}$ The Commission's Rules subsequently reflected this practice, during the reparations phase, and eventually the autonomous role of the victims or their representatives was extended to all phases before the Court. ${ }^{124}$ Currently, in the Inter-American system the original victim is a fully-fledged party in all phases before the Court, and the Inter-American Commission is represented in the Court proceedings by a delegate assisted by a legal officer. Similarly, under the 1950 European Convention, only States and the Commission could refer cases to the Court, and be part of proceedings before it. ${ }^{125}$ However, starting with the first case before the Court, Lawless $v$ Ireland, ${ }^{126}$ the European Commission and Court went far beyond these strictures. Despite 'stiff resistance' from the Irish government, ${ }^{127}$ the Court approved that the applicant be given access to the Commission's report, provided with an opportunity to comment, and be represented before the Court. ${ }^{128}$ This was the start of an evolution towards individual applicants gaining full 'rights of audience before the Court (via their lawyers) in the late 1970s', ${ }^{129}$ a position formalized in the Court's 1982 Rules. ${ }^{130}$

Taking a mid-way position between entirely denying and completely allowing access, the African Court's Rules give a discretion to the Court, 'if it deems it necessary', to hear the original complainant. ${ }^{131}$ Reference is made to Rule 45(2), in terms of which the Court may ask any person to obtain information, express an opinion or submit a report on any specific point. It is encouraging that in one of the first cases referred by the Commission to the Court, African Commission (Ogiek Community) v Kenya, the representative of the original complainant (Minority Rights Group) was allowed to take the floor and make representations. ${ }^{132}$

It is advisable that the Commission and Court should be guided by the evolution within the other two regional systems. First, the involvement of the victims and their representatives makes practical sense, as it is likely to ensure

123 ibid 43.

124 Art 24(1), Rules of Procedure of the Inter-American Commission (as amended in 2009): 'When the application has been admitted, the alleged victims or their duly accredited representatives may submit their pleadings, motions, and evidence autonomously throughout the proceedings.' $\quad{ }^{125}$ For an informative discussion, see Bates (n 70) 201-4.

126 Lawless v Ireland (No. 1) (Preliminary Objections and Questions of Procedure), Series A No. 1 (14 November 1960); Lawless v Ireland (No. 2), Series A No. 2 (7 April 1961); Lawless v Ireland (No. 3) (Merits), Series No. A 3 (1 July 1961).

127 Bates (n 70) 202.

${ }_{128}$ See C Morrisson, The Developing European Law of Human Rights (Sijthoff 1967) 60-70, who praises the Commission's 'political ingenuity' and describes the approach adopted as 'one of the outstanding landmarks in the international protection of human rights' (63). Morrisson emphasizes that the Convention did not shut out the individual complainant: 'Even if the individual could not be a party, it was still his case' (665). 129 Bates (n 70) 204.

130 Bates (n 70) $403 . \quad 131$ Rule 29(3)(c).

132 See the request to intervene under Rule of Court 29(3)(c) 'to be heard in the case as original complainants before the Commission' (para 14); the Court's granting the request (para 27); and reference to the Head of Law, Minority Rights Group, actually being heard by the Court (para 29) (Ogiek n 25). 
more intimate knowledge of the cases, and better access to witnesses and documentation. As a result, the burden on an overstretched Commission (and its staff) would be lessened; and a lesser load on the Commission may enhance referral to the Court. Second, allowing full autonomy to the original complainant would remove the ambiguity in the Commission's position, which at present fluctuates between being an independent arbiter of fact and law (when it decides the communication) and representing the interest of one party to the dispute (the applicant) before the Court.

In addition, placing the case back in the individual complainant's hands would be in line with the strong trend towards the humanization of international law, which lies at the core of the accountability procedures established under international human rights law. Such an approach would also align well with the greater prominence and acknowledgment of victims in other domains of international law, in particular, under international criminal law. ${ }^{133}$ These developments reverse previously prevailing stances that often silenced and excluded victims, by recognizing their autonomy, and the need for and benefit of their stories being told, and their presences being felt in public settings. ${ }^{134}$

\section{ADVISORY JURISDICTION}

By the end of 2016, the Court had issued only one advisory opinion, brought by the Committee of Experts on the Rights and Welfare of the Child. Of the other eight advisory requests submitted to the Court, ${ }^{135}$ the Court rejected ('struck

\footnotetext{
133 On victim participation before the ICC, see WA Schabas, An Introduction to the International Criminal Court (5th edn, Cambridge University Press 2017) 399-50, which he refers to as one of the 'great innovations in the Rome Statute' (399); on the role of victims in reparations before the ICC, see eg E Dwertmann, The Reparations System of the International Criminal Court (Martinus Nijhoff 2010).

134 See eg D Tietiens Meyers, Victims' Stories and the Advancement of Human Rights (Oxford University Press 2016).

135 These requests arrived at the Court since 2011, at an average of one per year for the period, as follows: 2011 (2); 2012 (2); 2013 (1); 2014 (2); 2015 (1); and 2016 (1). The Court's website list indicates 11 requests, which is misleading: The request by the Socio-Economic Rights Accountability Project (SERAP), Request 1/2012 (SERAP I request), was struck out; and subsequently resubmitted (as Request 1/2013) (SERAP II request); the same applies to the request by the Coalition on the International Criminal Court, Legal Defence \& Assistance Project (LEDAP), Civil Resource Development \& Documentation Center (CIRDDOC) and Women Advocates Documentation Center (WADRC), Request 1/2014 and Request 1/2015 (ICC I request; ICC II request). The statistical picture I paint takes the submission date of the first request into account, and not the second. SERAP II was finalized in 2017: African Court, Advisory Opinion, Request No 1/2013, Socio-Economic Rights and Accountability Project (SERAP Advisory Opinion) (26 May 2017).
} 
out') three, ${ }^{136}$ and one was withdrawn; ${ }^{137}$ leaving four pending before the Court. ${ }^{138}$

Compared to the Inter-American Court, the African Court has not in its formative years adopted a significant numbers of advisory opinions. In fact, the Inter-American Court adopted ten advisory opinions before adopting its first decision in a contentious case. ${ }^{139}$ In the early life of the Inter-American Court, with the Inter-American Commission's reticence to refer cases to the Court, advisory requests provided an alternative avenue to gain access to the Court. While the African Commission in its first decade of co-existence with the African Court displayed a similar reluctance to refer contentious cases to the African Court, access was still possible by way of direct access to the Court. The need for advisory opinions to invigorate the system was thus less pronounced in the case of the African Court.

To access the African Court's advisory jurisdiction, four requirements have to be met. ${ }^{140}$ The first relates to the Court's personal jurisdiction; the other three to the Court's substantive jurisdiction.

First, the entity making the request must be permitted to do so. The list of entities permitted to request advisory opinions in the African system is more inclusive than in the other regional systems. In fact, in the European system, only the Committee of Ministers may make such a request. ${ }^{141}$ By allowing advisory requests by OAS member States and all OAS organs, the InterAmerican system made access much wider. The African Court Protocol went

\footnotetext{
136 Requests by the Coalition on International Criminal Court (on the basis that the ICC Statute was not considered a 'human rights instrument') (ICC I request; ICC II request); and by the PanAfrican Lawyers Union and Southern African Litigation Centre (concerning the SADC Tribunal, on the basis that a similar case was pending before the African Commission) (The Pan African Lawyers' Union (PALU) and Southern African Litigation Centre, Request 2/2012 (SADC Tribunal request); and Libya, Request 2/2011 (no proof was provided that the individual presenting the request acted on behalf of the State). $\quad{ }^{137}$ Mali, Request 1/2011.

138 One by SERAP (concerning poverty as a human rights violation) (SERAP II request); another by the Centre for Human Rights (CHR) and Coalition of African Lesbians (concerning the word 'consider' in art 59 of Charter) (The Centre for Human Rights, University of Pretoria (CHR) \& The Coalition of African Lesbians (CAL), Request 2/2015 (Article 59(3) request); and a third by Rencontre Africain pour la defense des Droits de l'Homme, Request 2/2014 (RADDHO request); and a fourth by CHR and four others NGOs (concerning the phrases 'registered ... in order to be legally recognised' in art 6(d) of the Maputo Protocol (The Centre for Human Rights, Federation of Women Lawyers Kenya, Women's Legal Centre, Women Advocates Research and Documentation Centre and Zimbabwe Women Lawyers Association, Request 1/2016 (Article 6(d) request)). The Article 59(3) request was submitted on 2 November 2015; and the Article 6(d) request on 7 January 2016,

139 Between 1982 and 1987, the Court adopted 10 Advisory Opinions; in the following decade, the number declined to six opinions (see HF Ledesma, The Inter-American System for the Protection of Human Rights: Institutional and Procedural Aspects (2007) appendices at 979-80); see also J Pasqualucci, 'Advisory Practice and Procedure of the Inter-American Court of Human Rights: Contributing to the Evolution of International Human Rights Law' (2002) 38 StanJIntlL 241.

140 Art 4(1) of the Court Protocol; Rule 68 of the Court's Rules.

141 After the entry into force of Protocol 16 to the European Convention, the highest courts of member States may request advisory opinions from the European Court on questions of principle relating to the interpretation or application of the rights and freedoms defined in the Convention.
} 
one step further, by adding 'African organisations recognized by the AU' to the list of entities entitled to submit requests. Of the nine requests made so far, two were from States (although they were both abandoned); one request came from an AU organ (the African Children's Rights Committee); and the other six requests came from NGOs.

Are NGOs entitled to access the African Court through this route? This issue turns on the meaning ascribed to the term 'African organisations recognised by the AU' in Article 4(1) of the Protocol. This question has by the end of 2016 not been resolved. ${ }^{142}$ This phrase may be dissected into three elements: 'African' arguably relates to an organisation's geographical location (in Africa) and its management structure (being composed of Africans). The next element is 'organisation'. Adopting a contextual approach, and looking holistically at the provisions of the Protocol, it is noted that, in addition to its use in Article 4(1), the Protocol mentions the term 'organisation' on two other occasions: once, qualified by the word 'intergovernmental' ('intergovernmental organisations') 143 and once qualified by the word 'non-governmental' ('nongovernmental organisations). ${ }^{144}$ The term 'organisation' is therefore used in the Protocol as a generic term, of which the species includes entities that may be either intergovernmental or non-governmental. ${ }^{145}$ Unlike Article 5 (dealing with access in contentious proceedings), Article 4(1) does not make a distinction between governmental and non-governmental organisations. Following this logic, all 'organisations', including NGOs, therefore have the right to request a legal opinion. ${ }^{146}$ It is submitted that the third element, 'recognised by the AU', refers to recognition of an NGO by any of the organs or agencies of the African Union (AU). ${ }^{147}$ Under modern international law, it is trite that an agent is authorized to act on behalf of its principal within the mandate granted to the agent. The AU has a number of organs and agencies carrying out various mandated functions. Although the African Commission is not established in the AU Constitutive Act as an 'organ' of the AU, it has since 1987 existed as a de facto organ of the OAU/AU. Its legal existence is based on the African Charter, a separate legal instrument adopted by the OAU/AU. In any event, in one of its first decisions, the AU Assembly of Heads of State and Government decided that the African Commission 'shall henceforth operate within the framework of the African Union'. ${ }^{148}$ It will therefore be logical

142 Two of the NGO-initiated requests faltered for other reasons, and four were still pending (SERAP II request; Article 59(3) request; Article 6(d) request; RADDHO request). However, the Court decided this issue, finding that NGOs lack standing, in SERAP Advisory Opinion (n 135).

143 Art 5(1)(e) of the Court Protocol. $\quad{ }^{144}$ Art 5(3) of the Court Protocol.

145 Viljoen (n 3) 447.

146 F Ouguergouz The African Charter on Human and Peoples'Rights: A Comprehensive Agenda for Human Dignity and Sustainable Democracy in Africa (Brill 2003) 750.

147 The Court drew a distinction between the grant of observer status by 'the AU', on the one hand, and by 'AU organs', on the other (SERAP Advisory Opinion (n 135) paras 52-65. The implication of this ruling is that no NGO is in actual fact entitled to submit such a request.

148 AU Doc Assembly/AU/Dec.1(I) xi. 
and practical to consider NGOs which enjoy observer status with AU agencies such as the African Commission as being recognized by the AU within the terms of Article 4(1). ${ }^{149}$

The second requirement is that the subject matter of the request must not 'relate to an application pending before the African Commission'. One request, related to the suspension of the SADC Tribunal, failed at this hurdle, because a matter related to the SADC Tribunal was already pending before the Commission. ${ }^{150}$ The request to the Court was submitted on 23 November 2012, and the Court on 15 March 2013 declined the request. ${ }^{151}$ The case before the Commission, alleging that the suspension of the SADC Tribunal violated the African Charter (as well as the SADC Treaty and ICCPR), ${ }^{152}$ was concluded at the Commission's session ending on 5 November 2013. Because the Commission found no violation, the question arises whether the applicants are likely to be successful if they approached the Court anew with the same advisory request. It would seem that they are eligible to approach the Court again, given that there is no impediment, as the case is no longer pending before the Commission. The admissibility criteria under the African Charter, including the principle of res judicata, ${ }^{153}$ which apply in contentious proceedings, are not part of the requirements for advisory requests.

The third requirement is that the request should contain a question of a legal (rather than a purely political or economic) nature. It appears that one request, concerning the legal and human rights consequences of systemic poverty in Nigeria, was rejected on the basis that the issues raised did not reveal a sufficiently 'legal' basis. ${ }^{154}$

Fourth, the request must relate to the interpretation of 'the Charter or any other relevant human rights instruments'. Clearly, in addition to the African Charter, other AU human rights treaties such as the Women's Rights Protocol and Children's Rights Charter fall into this category. Resembling the scope of the Court's contentious jurisdiction, there is no restriction that these instruments have to be 'African'. Since there is no requirement that States be parties to the 'instruments' on which the request is based, a request may also relate to the UN human rights treaties (to which the relevant States may or may not be a party) and to other regional treaties, such as the European Convention on Human Rights. Also, the term 'instrument' allows

\footnotetext{
149 As Eno has observed, 'NGOs with observer status before the Commission are ipso facto organisations recognized by the OAU in terms of art 4(1) of the Protocol' (RW Eno, 'The Jurisdiction of the African Court on Human and Peoples' Rights' (2002) 2 AHRLJ 223 232). According to Ouguergouz, even a de facto working relationship between the AU and the NGO may constitute recognition for purposes of art 4 (Ouguergouz (n 146)).

150 SADC Tribunal request.

151 On the basis that on 5 December 2012 a matter, similarly related to the SADC Tribunal, was pending before the Commission, and in the absence of further information from the applicants.

152 Comm 409/12, Luke Munyandu Tembani and Benjamin John Freeth (represented by Norman Tjombe) $v$ Angola and Thirteen Others.

154 SERAP I request (resubmitted as SERAP II). 
for requests based on soft law standards. ${ }^{155}$ Consequently, encompassing matters related to all human rights treaties and all soft law standards related to human rights, the substantive scope of the Court's advisory opinions is immense.

The Court rejected one of the requests submitted to it, apparently-but not explicitly - on the basis that it did not relate to a 'human rights instrument'. ${ }^{156}$ The question posed by this request concerns the hierarchy of international obligations: for AU member States that are also parties to the ICC Statute, which is the higher obligation - the duty to cooperate under the ICC Statute, or the duty of non-cooperation established by some AU Assembly decisions? The Court held that the question is one of 'general public international law' and not human rights law. ${ }^{157}$ Despite the fact that the ICC Statute is clearly mentioned as the basis for the request, the Court held that the applicants have not 'specified the provisions of the Charter or any other international human rights instrument in respect of which the advisory opinion is being sought'. ${ }^{158}$

This view is open to two broad lines of criticism. On the one hand, the Court passed by the opportunity of providing its understanding of what the elements of a 'human rights instrument' are, and to express itself on the 'human rights status' of the ICC Statute. Adopting an approach that there are no rigid dividing lines between 'international human rights law' and 'international criminal justice', 159 the ICC Statute arguably qualifies as a 'human rights instrument'. The three core ICC crimes all result from egregious human rights violations; and the ICC is merely a mechanism for holding accountable those responsible for the most serious human rights violations. On the other hand, divorcing matters of 'public international law' from 'human rights law' is not reflecting the fact that international human rights law is a species of public international law. Some of the questions related to public international law are equally and crucially important to the specific area of international human rights law (IHRL). This sentiment is shared by Ouguergouz $\mathrm{J}$, who in his dissenting opinion in the ICC Advisory Opinion expressed the view that IHRL is based on,

\footnotetext{
155 eg the 2004 Guidelines for AU Electoral Observation and Monitoring Missions.

156 Request 1/2014 (Coalition en the International Criminal Court, Legal Defence \& Assistance Project (LEDAP), Civil Resource Development \& Documentation Center and Women Advocates Documentation Center (attempt to re-enlist as Request 1/2015 (Coalition on International Criminal Court LTD/GTE) was rejected); and Request 2/2014 (The African Movement for Human Rights Defence).

157 Request 1/2014 (Coalition en the International Criminal Court, Legal Defence \& Assistance Project (LEDAP), Civil Resource Development \& Documentation Center and Women Advocates Documentation Center, Order of 29 November 2015, para 18.

159 See eg WA Schabas, 'Synergy or Fragmentation? International Criminal Law and the European Convention on Human Rights' (2011) 9 JICJ 609; and A Huneeus, 'International Criminal Law by Other Means: The Quasi-Criminal Jurisdiction of the Human Rights Courts' (2013) 107 AJIL 1.
} 
and is 'by definition irrigated by' and 'imbibed by international law'. ${ }^{160}$ In his view, it is therefore inevitable that the interpretation of human rights would give rise to questions about treaty interpretation and the hierarchy of norms. ${ }^{161}$

Arriving at a different outcome, as far as the African Charter on Democracy, Elections and Governance (African Democracy Charter) is concerned, the Court in APDH v Côte d'Ivoire holds that an instrument's 'human rights-ness' has to be determined with reference to its aim and purpose. It then cites a number of provisions of the African Charter (rather than what is in dispute, the Democracy Charter and the ECOWAS Treaty) and without any further reference to the substance of these treaties, it concludes that, because these treaties give effect to the rights in the African Charter, they should be considered as 'human rights' treaties. ${ }^{162}$

The American Convention has an analogous provision, in that it allows the Court to interpret 'other treaties concerning the protection of human rights in the American States', 163 even if it is more restricted - it related only to treaties (not 'instruments'), and only to those treaties human rights protection 'in the American states'. Two opinions shed particular light on what a 'human rights' treaty entails. In response to request by Peru, the Court, in Other Treaties, interpreted the phrase 'other treaties' to include 'any provision dealing with the protection of human rights set forth in any international treaty applicable in the American States ... whatever be the principal purpose of such a treaty, and whether or not non-member states of the inter-American system are or have the right to become parties thereto'. ${ }^{164}$ In another case, Mexico requested whether Article 36(1)(a) of the Vienna Convention on Consular Relations falls under the Court's advisory jurisdiction. ${ }^{165}$ The answer to the question before the Court turned on whether this provision constitutes a treaty provision 'concerning the protection of human rights in the American States'. The Court held the view that, since Article 36(1)(a) 'endows a detained foreign national with individual rights that are the counterpart to the host State's correlative duties', ${ }^{166}$ this provision of the treaty falls within the Court's advisory jurisdiction.

Different to the African Court, the Inter-American Court has the explicit competence to give an opinion about the compatibility of a State's domestic laws with the treaties within the Court's jurisdiction. ${ }^{167}$ As long as the

\footnotetext{
160 Request 1/2014 (Coalition өn the International Criminal Court, Legal Defence \& Assistance Project (LEDAP), Civil Resource Development \& Documentation Center and Women Advocates Documentation Center, Order of 29 November 2015, Dissenting Opinion (J Ouguergouz).

161 Dissenting Opinion, para $19 . \quad 162$ APDH v Côte d'Ivoire, paras 63, 65.

163 Art 64(1).

164 Advisory Opinion OC-1/82, para 8.

165 Art 36(1)(a) provides that "consular officers shall be free to communicate with nationals of the sending State and to have access to them', and that nationals of the sending State 'shall have the same freedom with respect to communication and access to consular officers of the sending State'; see Advisory Opinion OC-16/99 (The Right to Information on Consular Assistance).

166 Advisory Opinion OC-16/99, para 84. 167 American Convention, art 64(2).
} 
requirements above are met, there is in my view no reason why the African Court should not also provide opinions on such questions.

\section{AMICUS CURIAE}

Individuals and NGOs may request to be admitted as amici curiae before the Court. Greater access by amici curiae is likely to enhance the quality of a court's judgments, and serves to make the court proceedings more democratically legitimate. ${ }^{168}$ Access to amici may bolster a party's argument by introducing supporting jurisprudence; it may enlarge the scope of the Court's inquiry by drawing attention to an issue not of immediate concern to the parties but relevant to the determination of an issue before the Court; and it may introduce additional points of view or arguments. This form of access also emerged as an important complement to the submissions of the parties in most international human rights fora, ${ }^{169}$ including the European and InterAmerican regional systems. ${ }^{170}$

Although the Protocol is silent on the possibility of amicus curiae proceedings, the Court's Rules indicate that the Court has a discretion to allow as amicus curiae any person whose 'assertions' or 'statements' may 'assist the Court in carrying out its task'. ${ }^{171}$ This position is further clarified in the Court's 2012 Practice Directions, which are specific in allowing individuals or organizations who want to act as amici curiae to 'submit a request to the Court'. ${ }^{172}$ The amicus is entitled to the application before the Court, as well as subsequent pleadings. ${ }^{173}$ Although the Practice Directions are not explicit on this point, in order for this procedure to be optimally accessible, these documents should not only be provided when requests have already been made, but also at the request of aspiring amici. Admitted amici may present their submissions during oral hearings. ${ }^{174}$

The Court has exercised its discretion to grant a request from amicus curiae intervention in at least four cases, ranging from provisional measures proceedings, decisions in interlocutory or preliminary proceedings, to merits

\footnotetext{
168 F Viljoen and AK Abebe, 'Amicus Curiae Participation before Regional Human Rights Bodies in Africa' (2014) 58 Journal of African Law 22. See also Inter-American Court of Human Rights, Kimel v Argentina, Judgment (Merits and Reparation) (2 May 2008) Series C No. 177, para 16.

169 D Shelton, 'The Participation of Nongovernmental Organizations in International Judicial Proceedings' (1994) 88 AJIL 611, 612.

170 See eg L Van den Eynde, 'An Empirical Look at the Amicus Curiae Practice of Human Rights NGOs before the European Court of Human Rights' (2013) 31 NQHR 271 (noting that, from 1986 to 2013, over 140 NGOs have been admitted as 'third-party interveners).

171 Rule 45, Rules of Court; Court's 2012 Practice Directions, para 47.

172 Court's 2012 Practice Directions, para 42.

173 Court's 2012 Practice Directions, para 44.

174 Not all cases lead to oral hearings. If the Court grants the request to act as amicus curiae, the person or organization making the request shall be notified by the Registrar and invited to make submissions, together with any annexes, at any point during the proceedings.
} 
decisions in contentious cases. Amici are also allowed to intervene in requests for advisory opinions. ${ }^{175}$ PALU was granted amicus status in a case concerning Libya, in which the Commission ordered provisional measures in 2011. ${ }^{176}$ The Coalition for an Effective African Court contributed as amicus in the Court's consideration of the validity and legal consequences of Rwanda's withdrawal of its Article 34(6) declaration. ${ }^{177}$ In Konate $v$ Burkina Faso, a group of eight NGOs submitted a joint amicus brief, and in APDH $v$ Côte d'Ivoire, the AU Commission and the African Institute for International Law submitted briefs; in both instances on the merits. ${ }^{178}$ In $A P D H v$ Côte d'Ivoire, the Court took the initiative to solicit the views of amici. ${ }^{179}$

There is no indication that the Court has so far refused any amicus request. In the matter of amicus curiae by the Rwandan National Commission for the Fight against Genocide (apparently as far as the merits are concerned). In subsequent proceedings, the Court denied the applicant's request to 'reject' the Commission's amicus brief. ${ }^{180}$ The Court reiterated that it has the discretion both to allow amici, and to 'take what it considers relevant and non-partisan from the amicus curiae'. ${ }^{181}$ Its approach is thus opting to be generous in admitting submissions, while emphasizing that it retains the authority to carefully scrutinize and attach weight to them.

The Court also adopted an accommodating approach to the substantive content of amicus briefs. It does not seem to require an element of 'novelty', but merely requires that amici should specify 'the contribution they would like to make with regard to the matter'. ${ }^{182}$ The amici in Konate illustrate how amici may complement an applicant's argument. While the applicant focused on the violation occasioned by the sentence of imprisonment imposed on him, the amici contended that any criminalization (that is, both custodial and non-custodial sentences) would violate the Charter. In a vote of 6 to 4 , the Court rejected the amici's argument. ${ }^{183}$

\section{CONCLUSION}

Between 2006 and 2016, the African Human Rights Court handed down merits decisions in eight contentious cases, finding violations in all of them. It declared

\footnotetext{
175 See eg the amicus brief of the Centre for Human Rights in the SERAP Advisory Opinion (n 135) paras 17, 33-36.

${ }_{176}$ African Commission (Bengazi) v Lybia App 4/2011, Order of Provisional Measures (25 March 2011). This case was eventually struck off the roll for a lack of presenting evidence, in 2013.

177 Ingabire Withdrawal, paras 43-47. 178 Konate, paras 141-143.

179 Court Practice Note, 2012, para 45: 'The Court on its own motion may invite an individual or organization to act as amicus curiae in a particular matter pending before it.'

180 Ingabire $v$ Rwanda, App 3/2014, Order (3 July 2016) para 38.

181 abire R R A R 2014, Order (3 July 20160 para 38 .

182 Court Practice Note (2012) para 42.

183 In its minority judgment, following the amici contention, no reference is made to the amici.
} 
only two cases inadmissible. Assessing the Court's accessibility to victims over the last decade depends on the yardstick that is applied. Measured, on the one hand, against the countless human rights violations befalling the African continent, and even the number of these instances ending up with the Afriea Commission, the Court's contribution has been extremely modest. However, the main reason for the small number of cases finding their way to the Court relates to the socio-economic and cultural context of most African States, captured by the 'dispute pyramid', in terms of which only a small percentage of sociological 'problems' are, in most of these States, ever conceptualized as 'legal disputes'. ${ }^{184}$ If, on the other hand, the case law of the Court's two regional antecedents in their first ten years is used as the unit of comparison, the African Court's record gives cause for more-optimism. In its first decade (1959-1969), the European Court decided only seven cases on their merits. ${ }^{185}$ The Inter-American Court decided three contentious cases in the first ten years of its functioning (1979-1989). ${ }^{186}$ Viewed from a historical perspective, the fact that the African Court decided slightly more cases is of lesser significance. When the African Court's first decade ran its course, international human rights and particularly the notion of individual access have seen great advances. By 1959, by contrast, the individual communications procedure was still a novelty, and was introduced as an exceptional, optional procedure that States had to specifically accept. Subsequently, there has been a proliferation of and much greater access to judicial institutions; and the advances in the experience of the other two courts by twenty-first century served as beacons of regional access.

In the same period, the Court adopted only one advisory opinion. Whatever yardstick is adopted, access to the African Court's advisory opinions has been limited. While the European Court has a very restricted advisory competence, the Inter-American Court in its first ten years handed down 11 advisory opinions. ${ }^{187}$

\footnotetext{
184 Ultimately, the issue of access remains framed by the limited number of cases that percolate through national systems. Access at the national level should be improved to enhance access at the regional level. In line with the principle of subsidiarity, accessing national courts must be the first port of call. It is thus in this arena where access has to be reinforced, for example by improving the effective functioning of domestic legal systems; fostering vibrant domestic legal cultures; and addressing impediments to justice such as inaccessible courts, excessive cost and corrupt officialdom. Achieving this is the responsibility of both States and civil society.

${ }_{185}$ Lawless v Ireland; De Becker v Belgium; Wemhoff v Germany; Neumeister v Austria; The Belgian Linguistic case; Stögmüller v Austria; and Matznetter v Austria. The number of cases increased to 20 in the next decade (1970-79); and to 144 in the following decade (1980-89) (see P Kampees (ed), A Systematic Guide to the Case Law of the European Court of Human Rights, 1960-1994 (Springer 1996); and B Mensah, European Human Rights Case Summaries 19602000 (Cavendish Publishing 2002)).

186 The Inter-American Court decided three contentious cases in the first ten years. These cases, Velásquez Rodrigues v Honduras, Firén Garbi and Solís Corralis v Honduras and Gordinez Cruz v Honduras were all submitted to the Court in 1986. Only the first and last of these proceeded to judgment on the merits. These decisions were rendered in 1989.

187 See HF Ledesma, The Inter-American System for the Protection of Human Rights: Institutional and Procedural Aspects (3rd edn, IIHR 2007) Apps at 967-982. The Inter-American Court mostly adopted advisory opinions over its first decade.
} 
In line with the practice before other regional Courts, amici curiae have found in the African Court a welcoming environment; and there is at least some indication that original complainants/victims would be allowed to have their voices heard before the Court. This form of access is in line with the important role that NGOs have played in getting the African human rights system off the ground, for example by submitting communications to the African Commission, and by raising human rights concerns and proposing measures during the Commission's public sessions.

To the extent that access to the African Court has been restricted, the main bottlenecks have been occasioned mainly by States and the Commission, and to a lesser degree by the Court itself, and by the African Union.

Direct access has emerged as the main access route to the Court. Seven out of the eight cases decided on the merits arrived at the Court via this avenue. However, only eight out of 30 State parties ever accepted direct access. The main factor hampering access has therefore not been the lack of universal ratification of the Court Protocol, but rather the small number of State parties to the Protocol accepting direct access to the Court. While it is disappointing that ratification has been waning as the decade progressed, the current group of 30 constitutes a relatively like-minded group, and should be the core around which the fledgling system should be allowed to grow into maturity. To improve direct access, there should therefore be an increase in the number of Article 34(6) declarations among the State parties to the Protocol, specifically by States that have already accepted direct judicial access to supranational judicial tribunals. Because it is clear that an Article 34(6) declaration is a necessary but not a sufficient condition for access, such a declaration should not be viewed as an end in itself, but as a basis on which to mobilize for its domestic use to overcome legal, political and institutional hurdles restricting domestic and regional access. The avalanche of cases reaching the Court from Tanzania underscores that access may be achieved if the right factorssuch as visibility; and the submission and resolution of cases that capture the societal imagination - are in alignment. As for advisory opinions, no State has successfully referred a request to the Court. States should consider making use of this mechanism to obtain an authoritative view on, for example, the compatibility of their domestic law prior to ratifying particular human rights treaties.

The Commission's limited referrals hampered indirect access. The absence of any case referred to the Court after being been dealt with on the merits, seems to be due to a lack of referral criteria, deficiencies in accurately establishing (non-) implementation, and uncertainty about the Commission's role, know-how and experience in presenting such cases before the Court. The Commission should overcome its reticence to refer by developing clear criteria for referral; by adopting a rebuttable presumption of referral under Rule 118(1); by establishing a reliable, accessible and updated mechanism to provide reliable data on (non-)compliance; and by devoting some of its admittedly limited 
resources to bolster its competence to present cases to the Court. The Commission should also consider making use, in appropriate instances, of the African Court's advisory jurisdiction.

Although access does not in the first instance depend on the Court itself, it has to some extent also impeded fuller access. While its admissibility decisions have not imposed a significant hurdle, the slow pace of finalizing cases resulted in fewer applicants obtaining actual remedies or other outcomes. It has however taken an important step to provide access to the legal representatives of victims in its Rules and practice, and it has been generous in admitting amici curiae. While the role of original complainants (victims) and their representatives in indirectly referred cases has been acknowledged, their place in contentious proceedings before the Court should be further clarified and formalized. Clarity about the original complainants' role may enhance the Commission's reticence to refer cases to the Court. The Court has not consistently advanced access to its advisory mandate. Its single advisory opinion did little to advance access; it narrowly interpreted its substantive advisory jurisdiction; it failed to deal expeditiously with requests, and passed by the opportunity to clarify the competence of NGOs to bring requests.

Indirect access to the African Children's Rights Committee would be enhanced by expediting an amendment to the Court Protocol. Although the AU took steps to undo the potential damage to access brought about by the Court's unhelpful advisory opinion, it has so far dragged its feet to make this a viable option. 